\section{The Effect of Huanglongbing on Young Citrus Tree Water Use}

\author{
Said A. Hamido ${ }^{1,3}$, Kelly T. Morgan ${ }^{1}$, and Davie M. Kadyampakeni ${ }^{2}$
}

ADDITIONAL INDEX WORDs. Candidatus Liberibacter asiaticus, evapotranspiration, sap flow, oil available water content, stem water potential

SUMmARY. Understanding the role of Huanglongbing (HLB) caused by Candidatus Liberibacter asiaticus on citrus (Citrus sp.) water use is critical for determining if changes in water management of commercial citrus orchards affected by this disease is necessary. Reference evapotranspiration $\left(\mathrm{ET}_{\mathrm{o}}\right)$ is the most used methodology for irrigation scheduling, particularly in light of reports that indicate the lack of water for irrigation will become a major problem in many places around the world including Florida. The objectives of this study were to determine citrus tree water relationship [water use, sap flow, and stem water potential $(\Psi)$ ] as affected by $\mathrm{ET}_{\mathrm{o}}$ and HLB. The study was initiated on Jan. 2014 on two sweet orange (Citrus sinensis) cultivars included Hamlin and Valencia grown in a fine sandy soil texture (sandy, siliceous, and hyberthermic Arenic Alaquods) in a greenhouse. Twelve weighing lysimeters of each cultivar (six HLB-affected and six nonaffected trees) were used to determine selected water relation parameters. Results indicated a significant reduction in water use, $\Psi$, and sap flow for affected trees when compared with nonaffected trees. Citrus water use of healthy trees during the 2-year study was $31 \%$ and $27 \%$ greater than HLB-affected trees for 'Hamlin' and 'Valencia', respectively. Lower water use of HLB-affected trees resulted in $10 \%$ and $\mathbf{1 5 \%}$ greater available soil water content than healthy 'Hamlin' and 'Valencia' trees, respectively. Therefore, reducing the water supply for HLB-affected trees than healthy trees may be a desirable practice that would lead to significant water savings.

$\mathrm{E}$ vapotranspiration (ET) is a dominating factor in the water cycle for most agricultural crops including citrus and plays a critical role in irrigation management (Bates et al., 2008; Castel et al., 1987; Jia et al., 2007; Morgan, 1992).

Citrus water requirements vary with environmental conditions and cultivar (Fares and Alva, 1999). Various studies indicated that citrus water use averaged between 1.1 and $6.5 \mathrm{~mm} \cdot \mathrm{d}^{-1}$ (Morgan et al., 2006; Rogers et al., 1983). Thus, estimates of water use coefficient $\left(K_{\mathrm{c}}\right)$ for citrus show a wide range of variations from 0.4 to 1.2 (Alves et al., 2007; Jia et al., 2007; Morgan et al., 2006). Decreasing available soil water content resulted in lower plant soil water uptake and thus lower $K_{\mathrm{c}}$ values (Morgan et al., 2006).

The effect of volumetric soil water content on ET is mainly controlled by the extent of irrigation managements and soil types (Chaudhury, 1985).

\footnotetext{
${ }^{1}$ Southwest Florida Research and Education Center, University of Florida, 2685 State Road 29 North, Immokalee, FL 34142

${ }^{2}$ Citrus Research and Education Center, University of Florida, 700 Experiment Station Road, Lake Alfred, FL 33850

${ }^{3}$ Corresponding author. E-mail: shamido@ufl.edu.

doi: 10.21273/HORTTECH03830-17
}

Within irrigated crops, meteorological parameters play the major role in controlling the ET processes. Although ET has been extensively studied in citrus (Boman, 1994; Morgan et al., 2006; Rogers et al., 1983) and other managed ecosystems (Igarashi et al., 2015; Ma et al., 2014; Moore et al., 2013), the phenomenon has not been documented for citrus affected with HLB.

HLB is the most critical disease in citrus production (Salifu et al., 2012). In Florida, the bacteria that putatively causes HLB are vectored by the asiatic citrus psyllid (Diaphorina citri). HLB causes roots to decline (Graham et al., 2013; Kadyampakeni et al., 2014b), which would reduce nutrient and water uptake. The infection rate of HLB is mainly controlled by the magnitude of the asiatic citrus psyllid population and tree age because the psyllids feed on new leaf growth (Brlansky et al., 2009).

Accurate estimation of citrus water use will aid improving irrigation management of both affected and nonaffected citrus trees which may result in water conservation and reduced loss of nutrients from excess irrigation. Kadyampakeni et al. (2014a) documented reduction in fibrous root density and soil water uptake under HLB-affected trees in Florida sandy soils but did not determine water uptake relative to ET. Thus, the objective was to determine how HLB may affect water relations of citrus, in particular water use, sap flow, and stem water potential.

\section{Materials and methods}

EXPERIMENTAL SETUP AND GREENHOUSE MEASUREMENTS. The experiment was conducted from 7 Jan. 2014 to 31 Oct. 2015 on 3-year-old sweet orange trees of 'Hamlin' (12 trees) and 'Valencia' (12 trees) grafted on 'Swingle' citrumelo (Citrus paradisi $\times$ Poncirus trifoliata) rootstocks transplanted into lysimeters located in a greenhouse at the University of Florida, Southwest Florida Research and Education Center (SWFREC) in Immokalee, FL (lat. $26.42^{\circ} \mathrm{N}$, long. $\left.81.42^{\circ} \mathrm{W}\right)$. Lysimeters in the greenhouse contained Immokalee fine sand soil (sandy, siliceous, and hyperthermic Arenic Alaquods). The 24 trees were selected based on leaf area, with similar leaf area measurements at the beginning of the experiment, and then placed in lysimeters inside the greenhouse, and arranged as a split plot randomized complete block design (RCBD) with two cultivars (Hamlin and Valencia) $\times$ two treatment (healthy control and HLB-affected trees) factorial.

\begin{tabular}{llll}
\hline $\begin{array}{l}\text { Units } \\
\text { To convert U.S. to SI, } \\
\text { multiply by }\end{array}$ & U.S. unit & SI unit & $\begin{array}{l}\text { To convert SI to U.S., } \\
\text { multiply by }\end{array}$ \\
\hline 100 & $\mathrm{bar}$ & $\mathrm{kPa}$ & 0.01 \\
0.1 & $\mathrm{bar}$ & $\mathrm{MPa}$ & 10 \\
0.3048 & $\mathrm{ft}$ & $\mathrm{m}$ & 3.2808 \\
0.0929 & $\mathrm{ft}^{2}$ & $\mathrm{~m}^{2}$ & 10.7639 \\
0.0283 & $\mathrm{ft}^{3}$ & $\mathrm{~m}^{3}$ & 35.3147 \\
2.54 & inch $(\mathrm{es})$ & $\mathrm{cm}$ & 0.3937 \\
25.4 & inch $(\mathrm{es})$ & $\mathrm{mm}$ & 0.0394 \\
0.4536 & $\mathrm{lb}$ & $\mathrm{kg}$ & 2.2046 \\
305.1517 & $\mathrm{oz} / \mathrm{ft}^{2}$ & $\mathrm{~g} \cdot \mathrm{m}^{-2}$ & 0.0033 \\
$\left({ }^{\circ} \mathrm{F}-32\right) \div 1.8$ & ${ }^{\circ} \mathrm{F}$ & ${ }^{\circ} \mathrm{C}$ & $\left({ }^{\circ} \mathrm{C} \times 1.8\right)+32$
\end{tabular}


Lysimeter dimensions were $73 \mathrm{~cm}$ (length) $\times 54 \mathrm{~cm}$ (width) $\times 40 \mathrm{~cm}$ (depth) with a soil surface area of $0.39 \mathrm{~m}^{2}$. Each cultivar had six HLBaffected and six unaffected trees evaluated for water demand. The method of inoculation with HLB was according to Handique et al. (2012). The trees had been maintained in a greenhouse free of the disease vector to allow for comparisons between HLBaffected and unaffected trees. Trees were confirmed (Dec. 2013) for presence of HLB disease by polymerase chain reaction [PCR (Handique et al., 2012)] and transplanted into lysimeters. Each lysimeter was maintained on a scale (Campbell Scientific, Logan, UT) and weight measured every $30 \mathrm{~min}$. The lysimeters were irrigated daily to a base weight reflecting the water holding capacity of the soil within each lysimeter. Daily ET was determined by calculating the weight loss between water holding capacity and irrigation the next morning.

METEOROLOGICAL MEASUREMENTS. A weather station (HOBO H21-001; Onset Computer Corp., Bourne, MA) was mounted in the greenhouse for weather parameter measurements at $2 \mathrm{~m}$ height (Allen et al., 1998). Measurements [solar radiation using a silicon pyranometer smart sensor (S-LIB-M003; Onset Computer Corp.), air temperature, and relative humidity (RH) using a 12-bit temperature/ RH smart sensor (S-LIB-M002; Onset Computer Corp.)] were recorded every $30 \mathrm{~min}$. In addition, meteorological parameters from the Florida Automated Weather Network (FAWN) station included solar radiation, air temperature, and $\mathrm{RH}$ were used for comparison purpose only from Jan. 2014 to Oct. 2015. The FAWN station was located $300 \mathrm{~m}$ from the greenhouse and measured ambient climate conditions. Daily $\mathrm{ET}_{\mathrm{o}}$ was calculated from FAWN measurements that were used to validate the calculated $\mathrm{ET}_{\mathrm{o}}$ for the greenhouse where $\mathrm{ET}_{\mathrm{o}}$ was estimated according to Eq. [1]. Crop ET $\left(\mathrm{ET}_{\mathrm{c}}\right)$ was calculated daily for each lysimeter based on daily water weight loss, water density, and soil volume (Eq. [2]).

REFERENCE EVAPOTRANSPIRATION FAO Penman-Monteith 56 MEthod. $\mathrm{ET}_{\mathrm{o}}$, the rate of available soil water vaporized from crop surfaces (Jensen et al., 1990), was calculated as described by Zotarelli et al. (2010) (Eq. [1]):

Table 1. Means representing the effect of Huanlongbing (HLB) disease on total available water (TAW) in soils, stem water potential, and sap flow of two sweet orange cultivars (Hamlin and Valencia) in comparison with healthy trees in the greenhouse study during 2014 and 2015.

\begin{tabular}{|c|c|c|c|c|c|}
\hline \multirow[b]{2}{*}{ Cultivar } & \multicolumn{2}{|c|}{ TAW (\%) } & \multicolumn{2}{|c|}{ Stem water potential $(\mathrm{MPa})^{\mathrm{z}}$} & \multirow{2}{*}{$\begin{array}{c}\text { Sap flow } \\
\left(\mathrm{g} \cdot \mathrm{m}^{-2} \cdot \mathrm{h}^{-1}\right)^{\mathrm{z}}\end{array}$} \\
\hline & 2014 & 2015 & 2014 & 2015 & \\
\hline Hamlin with HLB & $98 \mathrm{a}^{\mathrm{y}}$ & $99 \mathrm{a}$ & $-1.3 b$ & $-1.7 \mathrm{~b}$ & $28.59 \mathrm{cb}$ \\
\hline Hamlin -healthy & $89 \mathrm{~b}$ & $88 \mathrm{~b}$ & $-1.1 \mathrm{a}$ & $-1.1 \mathrm{a}$ & $69.13 \mathrm{a}$ \\
\hline Valencia with HLB & $95 \mathrm{a}$ & $98 \mathrm{a}$ & $-1.2 \mathrm{~b}$ & $-1.8 \mathrm{~b}$ & $16.88 \mathrm{c}$ \\
\hline Valencia -healthy & $83 \mathrm{~b}$ & $86 \mathrm{~b}$ & $-0.9 \mathrm{a}$ & $-0.9 \mathrm{a}$ & $38.56 \mathrm{~b}$ \\
\hline
\end{tabular}

${ }^{\mathrm{z}} 1 \mathrm{MPa}=10 \mathrm{bar}, 1 \mathrm{~g} \cdot \mathrm{m}^{-2}=0.0033 \mathrm{oz} / \mathrm{ft}^{2}$

${ }^{y}$ Means in the same column with the same letter are not significantly different at $\alpha \leq 0.05$.
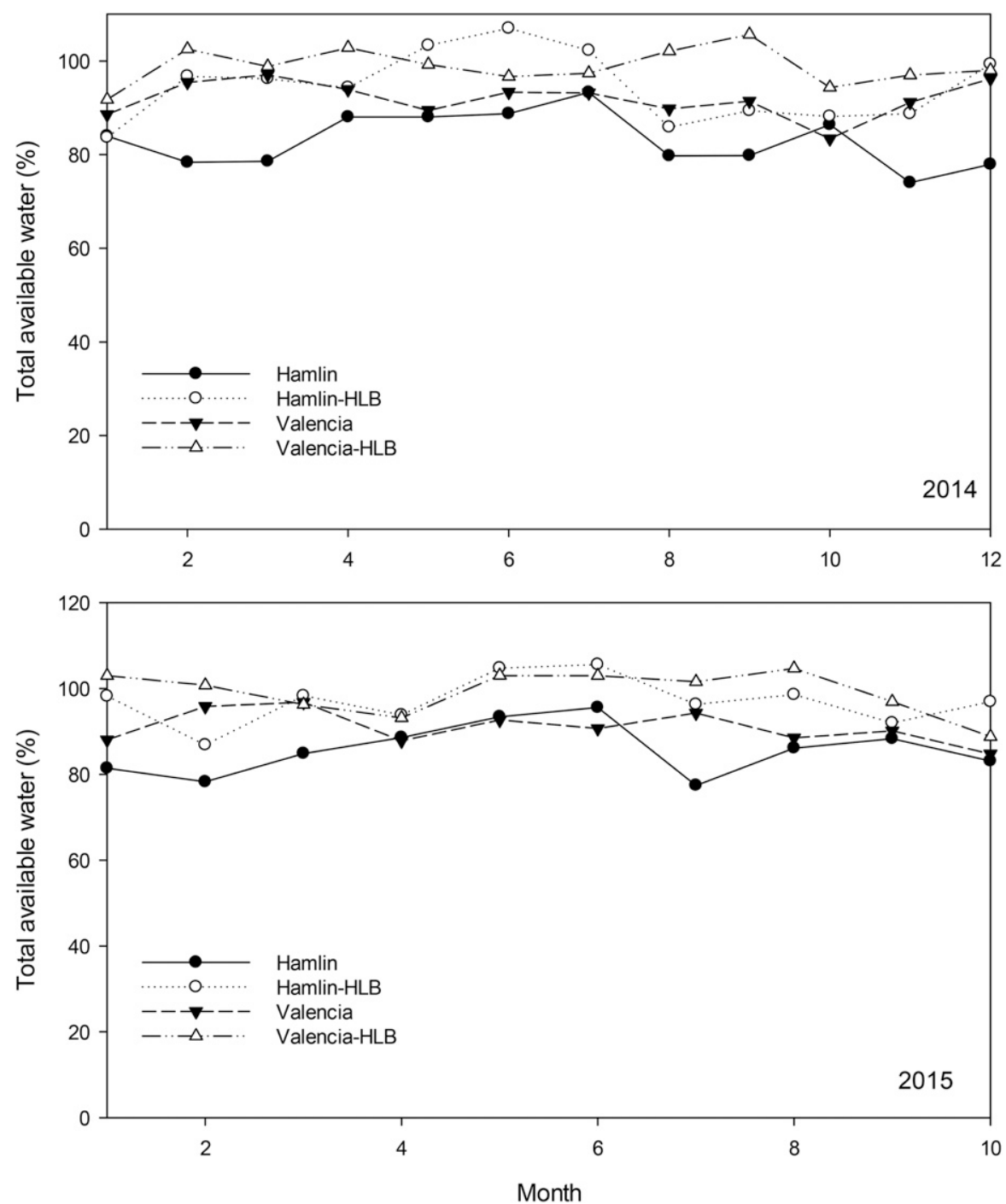

Fig. 1. Effect of Huanglongbing (HLB) affected and nonaffected sweet orange trees ('Hamlin' and 'Valencia') on soil total available water content in the top soil [0-30 cm (11.8 inches)] in lysimeters under greenhouse conditions located at the Southwest Florida Research and Education Center (Immokalee, FL) from Jan. 2014 through Oct. 2015.

$\mathrm{ET}_{\mathrm{O}}=\frac{0.40 \Delta(\mathrm{Rn}-G)+\gamma \frac{900}{\mathrm{~T}+273} u_{2}\left(e_{\mathrm{s}}-e_{\mathrm{a}}\right)}{\Delta+\gamma\left(1+0.3 u_{2}\right)}$

where $\mathrm{ET}_{\mathrm{o}}=$ reference evapotranspiration $\left(\mathrm{mm} \cdot \mathrm{d}^{-1}\right), \mathrm{Rn}=$ net radiation at the crop surface $\left(\mathrm{MJ} \cdot \mathrm{m}^{-2} \cdot \mathrm{d}^{-1}\right), G=$ soil heat flux density $\left(\mathrm{MJ} \cdot \mathrm{m}^{-2} \cdot \mathrm{d}^{-1}\right), T=$ mean daily air temperature at $2 \mathrm{~m}$ height $\left({ }^{\circ} \mathrm{C}\right), u_{2}=$ wind speed at $2 \mathrm{~m}$ height $\left(\mathrm{m} \cdot \mathrm{s}^{-1}\right), e_{\mathrm{s}}=$ saturation vapor pressure $(\mathrm{kPa}), e_{\mathrm{a}}=$ actual vapor pressure $(\mathrm{kPa})$, $\mathrm{e}_{\mathrm{s}}-\mathrm{e}_{\mathrm{a}}=$ saturation vapor pressure deficit 
Table 2. Measured reference evapotranspiration $\left(\mathrm{ET}_{\mathrm{o}}\right)$ and water use $\left(\mathrm{ET}_{\mathrm{c}}\right)$ for Huanglongbing (HLB) affected and healthy trees of two sweet orange cultivars (Hamlin and Valencia) inside a greenhouse at the Southwest Florida Research and Education Center (Immokalee, FL) from Jan. 2014 through Oct. 2015.

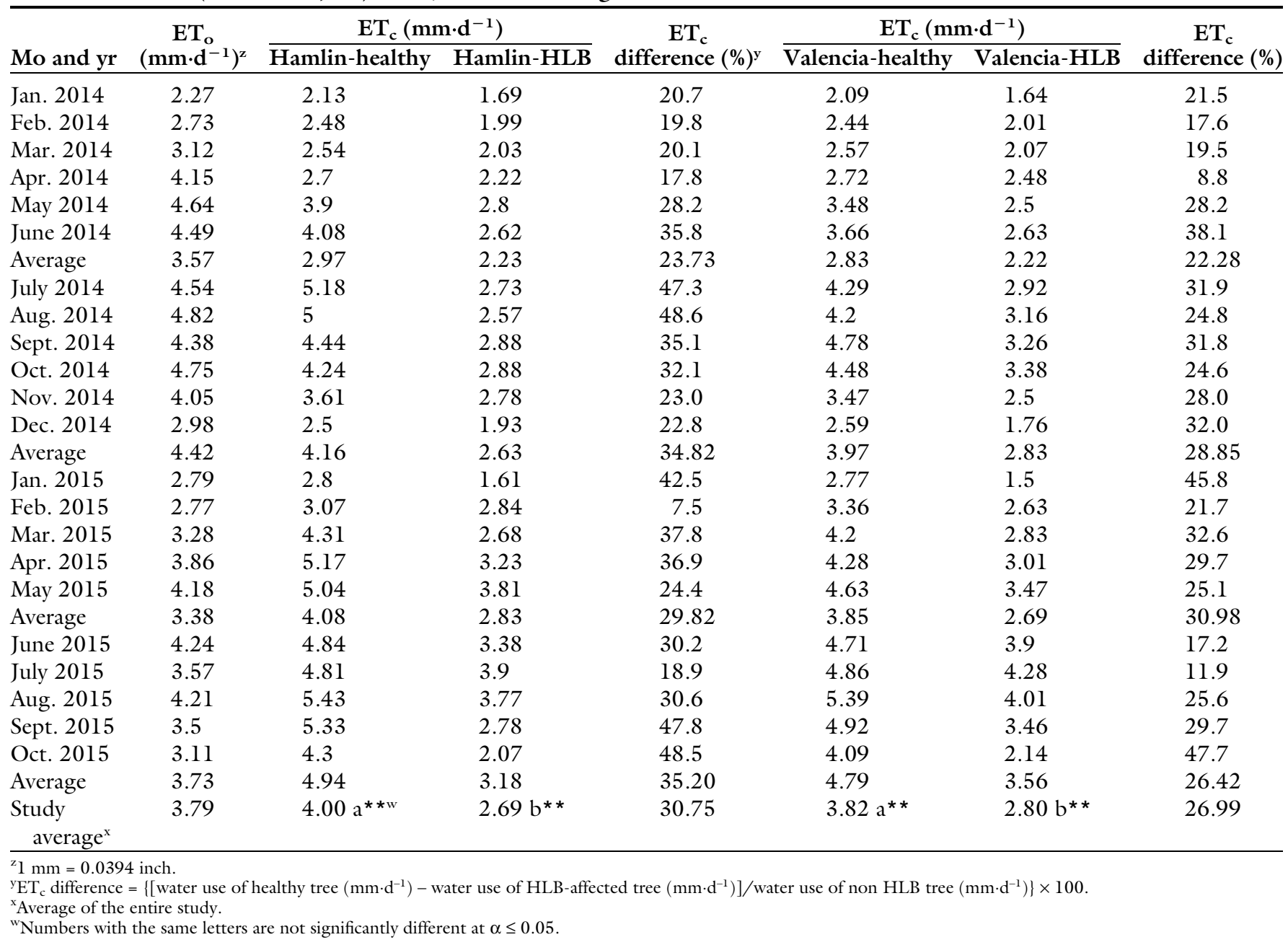

$(\mathrm{kPa}), \Delta=$ slope vapor pressure curve $\left(\mathrm{kPa} \cdot{ }^{\circ} \mathrm{C}^{-1}\right), \gamma=$ psychometric constant $\left(\mathrm{kPa} \cdot{ }^{\circ} \mathrm{C}^{-1}\right)$.

TOTAL AVAILABLE WATER CONTENT. Volumetric soil water content for each lysimeter was measured at 30 $\mathrm{cm}$ soil depth every $30 \mathrm{~min}$ using one soil water time domain reflectometers [TDR (CS650; Campbell Scientific)] per lysimeter connected to the data logger (CR1000; Campbell Scientific). Total available water (TAW) was determined from the moisture release curve using Eq. [2].

$$
\begin{aligned}
\operatorname{TAW}(\%)= & {[(\mathrm{WC}-\mathrm{FC}) /(\mathrm{FC}-\mathrm{PWP})] } \\
& \times 100
\end{aligned}
$$

where TAW is the total available water, WC is the soil water content, FC $(10 \%)$ is the field capacity, and
PWP [1\% (Obreza et al., 1997)] is the permanent wilting point.

Citrus WATER USE MEASUREMENT. Water use was determined as follows: Daily lysimeter $\left(\mathrm{ET}_{\mathrm{Lys}}\right)$ water use estimation:

$$
\begin{aligned}
& \operatorname{ET}_{\text {Lys }}\left(\mathrm{mm} \cdot \mathrm{d}^{-1}\right) \\
&=\left[\mathrm{LW}_{\mathrm{d}=0}-\mathrm{LW}_{\mathrm{d}=1}\left(\mathrm{~kg} \cdot \mathrm{d}^{-1}\right)\right] \\
&\left(1 \mathrm{~m}^{3} / 1000 \mathrm{~kg}\right)\left[1 / \mathrm{SA}_{\text {Lys }}\left(\mathrm{m}^{2}\right)\right]
\end{aligned}
$$

where $\mathrm{ET}_{\mathrm{Lys}}$ is the evapotranspiration from the lysimeter, LW is lysimeter weight at the beginning of the day $(d=0)$ and $1 \mathrm{~d}$ later $(d=1)$, and $\mathrm{SA}_{\mathrm{Lys}}$ is the surface area of the soil in the lysimeter which was $0.4125 \mathrm{~m}^{2}$.

This equation assumes that the effective evaporative surface area of the tree and lysimeter is equal to the surface area of the soil in the lysimeter.
Stem water potential. Stem water potential was determined twice per month (during Feb. and June 2014 and from July through Oct. 2015) using a Portable Plant Water Status Console (Soilmoisture Equipment Corp., Santa Barbara, CA). Two representative leaves per tree (24 trees) were randomly selected and covered with plastic and aluminum foil $24 \mathrm{~h}$ before measurements. Selected leaves were cut close to the plant stem with a razor blade and placed into the pressure chamber. The chamber was pressurized until the exudation of water and the pressure was recorded.

CitRUS SAP FLOW MEASUREMENTS. Sap flow was measured on 8-21 Oct. 2015 by the heat balance method using an automated flow system (Flow321K; Dynamax, Houston, TX) using trunk heat balance gauges (models 
Month - 2014

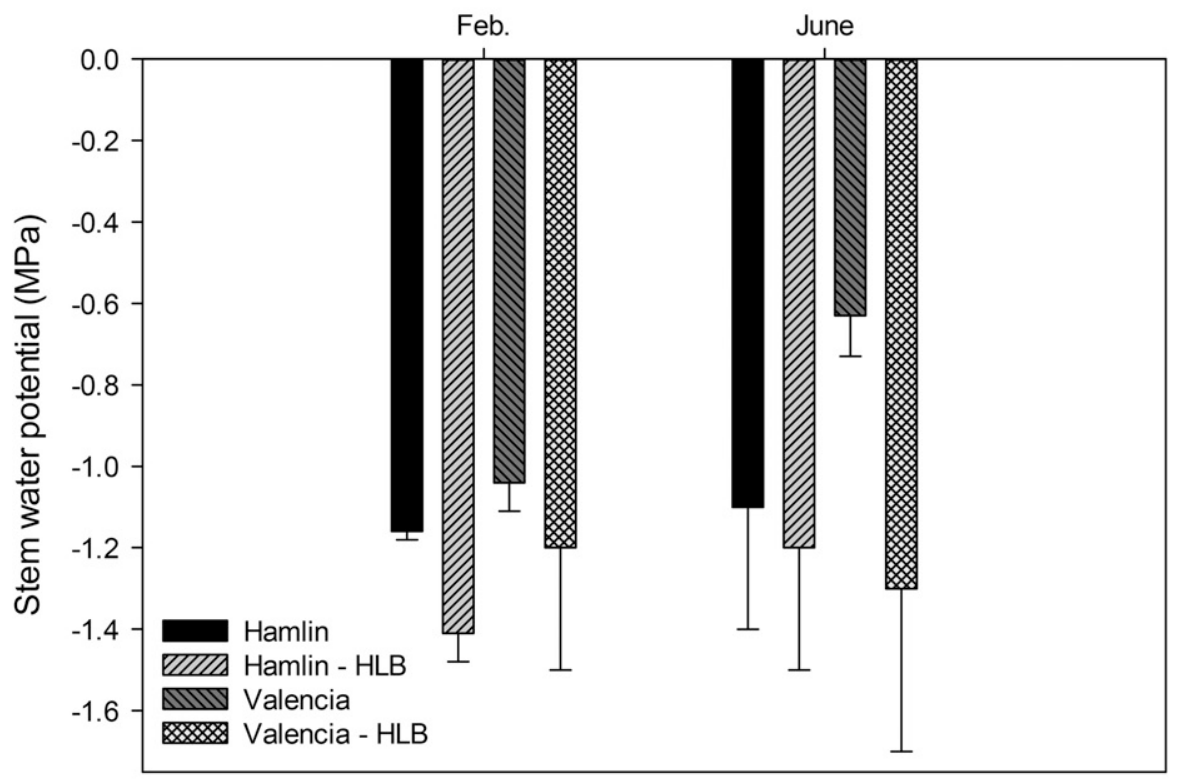

Month - 2015

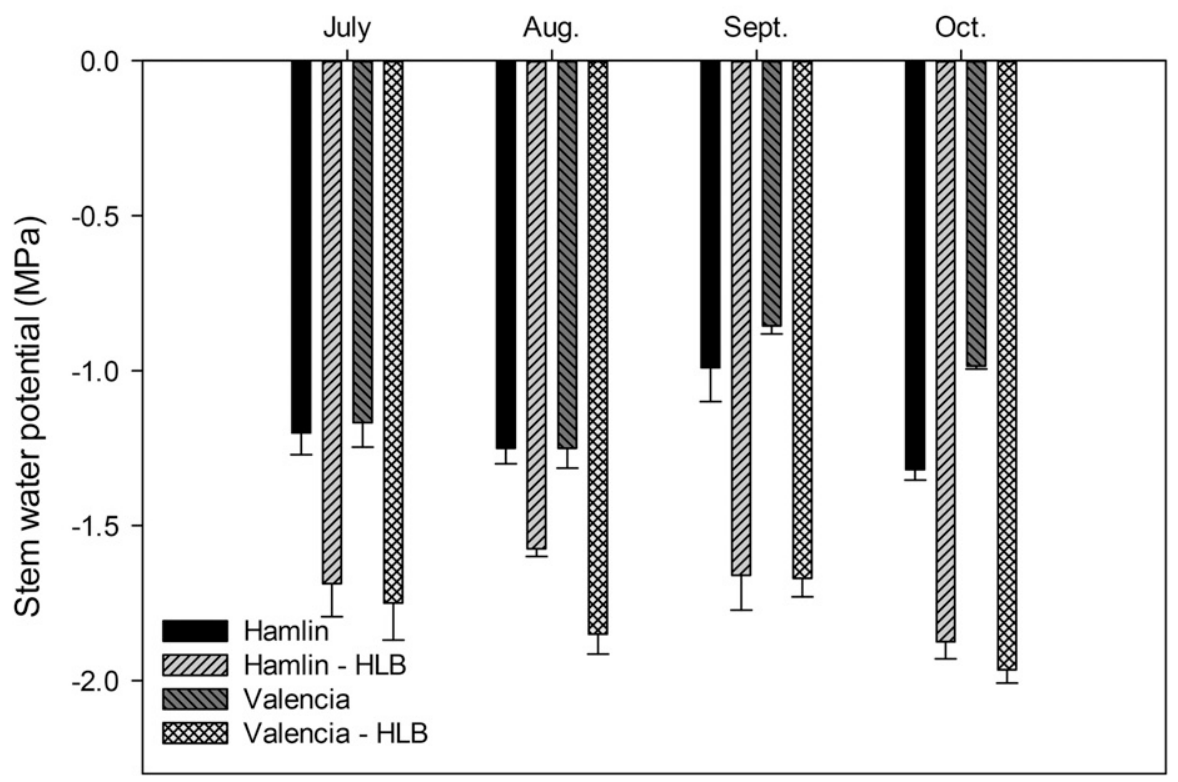

Fig. 2. Effect of Huanglongbing (HLB) affected and nonaffected sweet orange trees ('Hamlin' and 'Valencia') on stem water potential under the greenhouse conditions at the Southwest Florida Research and Education Center (Immokalee, FL) between Feb. 2014 and Oct. 2015; $1 \mathrm{MPa}=10$ bar.

SGA13, SGB16, SGB19, and SGB25; Dynamax). Trunk diameters ranged from 15 to $28 \mathrm{~mm}$. Gauge installation was performed as described by the manufacturer (Dynamax, 1990). Trunks were coated with silicone grease (Dow Corning 4; Dow Corning, Midland, MI) to improve thermal contact and reduce trunk injury. Sap flow measurements were taken for 14 trees (four control healthy trees and three HLB- affected trees from each cultivar) with one sensor per tree.

Statistical analysis. Each cultivar (Hamlin and Valencia) was considered as a plot with two subplots (healthy and HLB-affected trees), then the two cultivars were considered as a block which replicated six times. Analyses of variance (ANOVA) was used to identify significant effects in SAS (version 9.1.3 for Windows;
SAS Institute, Cary, NC) using the general linear model procedure (PROC GLM). Least significant difference (LSD) was used to determine significant differences among means at $P<0.05$. Correlations and linear regression between variables were determined using Sigma Plot software (version 12.3; Systat Software, San Jose, CA).

\section{Results and discussion}

Meteorological MEASUREMENTS. Average daily air temperatures $\left({ }^{\circ} \mathrm{C}\right)$, $\mathrm{RH}(\%)$, and solar radiation $\left(\mathrm{W} \cdot \mathrm{m}^{-2}\right)$ varied significantly $(P<0.0001)$ during the experimental period between the greenhouse and FAWN measurements (data not shown). Average air temperature inside the greenhouse was always higher than outside by $2.9{ }^{\circ} \mathrm{C}$. Yang et al. (2003) reported similar observation where air temperature in the greenhouse was greater than outside by an average of $3.5^{\circ} \mathrm{C}$. In agreement with our observations, they also found that the RH fluctuated inside and outside the greenhouse. On average, $\mathrm{RH}$ inside the greenhouse was lower than outside by $11 \%$. However, $\mathrm{ET}_{\mathrm{o}}$ during our study did not vary significantly $(P=$ 0.45 ) between the greenhouse and the field station (FAWN). An early greenhouse study reported that measured $\mathrm{ET}_{\mathrm{O}}$ varied significantly from $0.6 \mathrm{~mm} \cdot \mathrm{d}^{-1}$ in a cold weather to 7.0 $\mathrm{mm} \cdot \mathrm{d}^{-1}$ in a warm weather (Yang et al., 2003). In this study, measured $\mathrm{ET}_{\mathrm{o}}$ ranged from 2.3 in Jan. 2014 to $4.8 \mathrm{~mm} \cdot \mathrm{d}^{-1}$ in Aug. 2014. Jia et al. (2007) reported similar $\mathrm{ET}_{\mathrm{o}}$ values for flatwoods citrus, sandy soils located in coastal areas with water table close to the surface (Boman, 1994), in Florida ranged between 2.4 in Dec. 2004 and 5.2 in July 2005.

TAW CONTENTS. Generally, TAW was significant greater $(P<$ 0.0001 ) for HLB-affected trees compared with healthy trees during the 2 -year study (Table 1 ). On average, soils under HLB-affected trees maintained higher soil water content (Fig. 1) estimated to be $10 \%$ and $15 \%$ greater than soil under healthy 'Hamlin' and 'Valencia' trees, respectively. The reason behind higher TAW under HLBaffected trees could be related to lower root densities under affected trees (Hamido et al., 2016; Kadyampakeni et al., 2014a), which limits crop water uptake. Lower TAW under control 


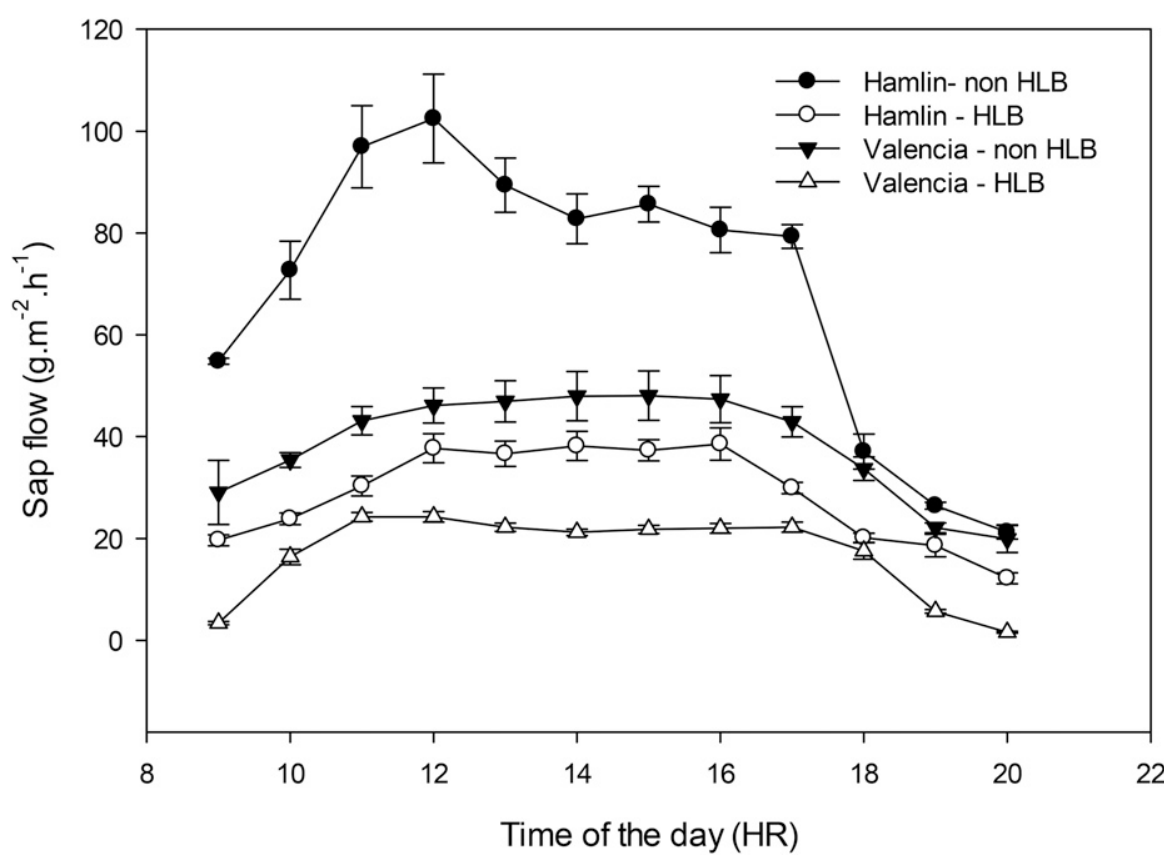

Fig. 3. Effect of Huanglongbing (HLB) affected and nonaffected sweet orange trees ('Hamlin' and 'Valencia') on sap flow under the greenhouse conditions located at the Southwest Florida Research and Education Center (Immokalee, FL) during 8-21 Oct. $2015 ; 1 \mathrm{~g} \cdot \mathrm{m}^{-2}=0.0033 \mathrm{oz} / \mathrm{ft}^{2}$.

trees indicates greater water uptake by the larger canopy and root areas than HLB-affected trees.

Soil TAW indicated that there was a significant difference $(P<$ $0.0001)$ related to the HLB infection. TAW measured during summer (July) 2014 were the highest values, ranging from 93\%, 97\%, 93\%, to $102 \%$ for 'Valencia', 'Valencia' with HLB, 'Hamlin', and 'Hamlin' with HLB, respectively, and were lowest during winter (January) with measured values ranging from $88 \%, 91 \%, 83 \%$, to $83 \%$ under 'Valencia', 'Valencia' with HLB, 'Hamlin', and 'Hamlin' with HLB, respectively. Generally, daily TAW averaged $84 \%, 96 \%, 91 \%$, and 98\% under 'Valencia', 'Valencia' with HLB, 'Hamlin', and 'Hamlin' with HLB, respectively.

Citrus water use. During the study, average $\mathrm{ET}_{\mathrm{c}}$ for healthy trees were $31 \%$ and $27 \%$ greater than for HLB-affected trees for 'Hamlin' and 'Valencia' trees, respectively. Previous studies reported similar citrus water use averages under different environmental conditions. For example, estimated $\mathrm{ET}_{\mathrm{c}}$ values for citrus ranged from 1.3 to $5 \mathrm{~mm} \cdot \mathrm{d}^{-1}$ in Sao Paulo, Brazil (Alves et al., 2007), from 1.7 to $5 \mathrm{~mm} \cdot \mathrm{d}^{-1}$ in flatwoods citrus (Rogers et al., 1983), or from 1.8 to $4.4 \mathrm{~mm} \cdot \mathrm{d}^{-1}$ for ridge citrus, soils with unconfined coarse sand (Boman, 1994; Jia et al., 2007; Romero et al., 2009). Furthermore, Morgan et al. (2006) represented citrus $\mathrm{ET}_{\mathrm{c}}$ values ranged between 1.1 and $6.5 \mathrm{~mm} \cdot \mathrm{d}^{-1}$ in Florida sandy soils.

Daily water use by HLB-affected trees were always lower than $\mathrm{ET}_{\mathrm{c}}$ of non-HLB trees (Table 2), which is at least partly due to lower root density compared with healthy trees. $\mathrm{ET}_{\mathrm{c}}$ for control (healthy) trees were $21 \%$ ('Hamlin') and 22\% ('Valencia') greater than HLB-affected trees in Jan. 2014 (winter) and 47\% ('Hamlin') and 32\% ('Valencia') in July 2014 (summer).

Statistical analysis showed no significant difference in $\mathrm{ET}_{\mathrm{c}}$ between cultivars and time of sampling (Table 2). However, differences were related to HLB effect with each cultivar. For example, ANOVA of ET data for the 2 years (Jan. 2014 through Oct. 2015) showed that the HLB effect $(P<0.0001, P<0.0001)$ and time of sampling $(P<0.01, P<0.0001)$ are significant; however, the interaction between both of them $(P=0.28$, $P=0.34$ ) for 2014 and 2015, respectively, was not significant.

Stem water potential. Stem water potential is considered to be the most dependable indicator of plant water status (Chone et al., 2001). The average $\Psi$ for healthy 'Valencia' trees was -1.0 MPa, 33\% greater than measured for HLBaffected trees $(-1.5)$. Furthermore, highest values of $\Psi(-0.63 \pm 0.1$ and $-0.86 \pm 0.03 \mathrm{MPa})$ were observed during June 2014 and Sept. 2015 under 'Valencia' control trees and were $50 \%$ and $39 \%$ greater than that measured in Aug. $2015(-1.25 \pm$ 0.06 ) (Fig. 2). In general, lower $\Psi$ were reported in Oct. 2015 ranging from $-1.88 \pm 0.05$ to $-1.97 \pm 0.04$ MPa for HLB-affected 'Hamlin' and 'Valencia' trees, respectively.

Highest stem $\Psi$ values ranged from $-0.99 \pm 0.11$ to $-0.86 \pm 0.03$ MPa for 'Hamlin' and 'Valencia' control trees during the same period, respectively. Similar observations were reported for water stressed with stem $\Psi$ close to $2 \mathrm{MPa}$ and nonstressed citrus trees with values less than I MPa by Gasque et al. (2016) and Hamido et al. (2017), respectively. Also, McCutchan and Shackel (1992) reported that irrigated prune trees showed stem $\Psi$ values between -0.5 and -1.0 whereas nonirrigated trees showed a $-3.0 \mathrm{MPa}$ value. Shackel et al. (1997) indicated that stem $\Psi$ for almond trees responds differently under different irrigation management scenarios. They concluded that stem $\Psi$ of almond trees varied according to the volume of water supplied. For example, stem $\Psi$ declined from -0.8 to $-1.5 \mathrm{MPa}$ when water volume reduced from 900 to $50 \mathrm{~mm}$, respectively.

SAP FLOw. In general, sap flow increased after sunrise, reached maximum flow between 12 and $14 \mathrm{~h}$, and declined thereafter (Fig. 3). The decline in sap flow continued as sampling time increased after $15 \mathrm{~h}$. Published studies reported similar diurnal sap flow trends under banana (Musa sp.) plantation (Haijun et al., 2015), citrus groves (Hamido et al., 2017; Kadyampakeni et al., 2014b), and jujube (Ziziphus jujuba) plantations (Chen et al., 2014).

Sap flow of HLB-affected trees was significantly lower $(P \leq 0.05)$ than control citrus trees indicating lower water uptake. Sap flow in HLB-affected trees was lower than that for control trees by $59 \%$ and $56 \%$ under 'Hamlin' and 'Valencia' citrus trees, respectively. The reason 
may be due to greater leaf areas and root system of control trees than HLB-affected trees, which might have resulted in greater water absorption by roots and increased water use due to photosynthetic activities in the leaves.

\section{Conclusions}

Determining crop coefficient under field condition from greenhouse data are subject to errors. However, if one were to estimate $K_{\mathrm{c}}$ from the data presented in this article using Eq. [4] below. Average $K_{\mathrm{c}}$ may be ranged from about 0.85 for healthy trees to 0.64 for HLBaffected trees during 2014. Estimated $K_{\mathrm{c}}$ may be higher in the second year with 1.14 to 1.34 for healthy trees and 0.79 to 0.95 for HLB-affected 'Hamlin' and 'Valencia' trees, respectively. In our study, crop coefficients under healthy trees were 1.5 and 1.6 times greater than that under HLB-affected 'Hamlin' and 'Valencia' trees, respectively.

$$
K_{\mathrm{c}}=\mathrm{ET}_{\mathrm{c}} / \mathrm{ET}_{\mathrm{o}}
$$

$K_{\mathrm{c}}$ values concurred with those measured by other researchers (Alves et al., 2007; Yang et al., 2003). For example, Alves et al. (2007) reported monthly $K_{\mathrm{c}}$ average for citrus trees ranged from 0.9 to 1.11. Boman (1994) reported that the $K_{\mathrm{c}}$ values for 5-year-old orange trees grown in lysimeters increased from 0.6 during December-February to 1.1 during June-July. Hla et al. (1997) reported daily $K_{\mathrm{c}}$ for 7 -year-old citrus trees from 0.53 in December through February to 1.4 in mid-July.

The experiment concluded that healthy trees consumed more water than HLB-affected trees. The water consumption was significant and affected by other tree physiological functions including sap flow and stem water potential. All trees were irrigated daily to maintain soil water content near field capacity for optimum water uptake; the HLB-affected trees consumed less water than healthy trees which could have been directly related to root density and lower canopy surface area. Lower water consumption by HLB-affected trees resulted in higher soil water contents compared with soil containing healthy trees. Therefore, reducing the water volume for HLBaffected trees than healthy trees may be a desirable practice to conserve water in excessively drained sandy soils. However, more research is needed to confirm our results on a grove scale under noncontrolled environments.

\section{Literature cited}

Allen, R.G., L.S. Pereira, D. Raes, and M. Smith. 1998. Crop evapotranspiration. Guidelines for computing crop water requirements. FAO Irr. Drainage Paper 56.

Alves, J., Jr., M.V. Folegatti, L.R. Parsons, W. Bandaranayake, C.R. da Silva, T.J.A. da Silva, and L.F.S.M. Campeche. 2007. Determination of the crop coefficient for grafted 'Tahiti' lime trees and soil evaporation coefficient of rhodic kandiudalf clay soil in Sao Paulo, Brazil. Irrig. Sci. 25:419-428.

Bates, B.C., Z.W. Kundzewicz, S. Wu, and J.P. Palutikof. 2008. Climate change and water. Technical paper of the intergovernmental panel on climate change. IPCC, Geneva, Switzerland.

Boman, B.J. 1994. Evapotranspiration by young Florida flatwoods citrus trees. J. Irr. Drainage Eng. 120:81-88.

Brlansky, R.H., M.M. Dewdney, and M. E. Rogers. 2009. Florida citrus pest management guide: Huanglongbing (citrus greening). Extension Digital Information Source (EDIS): PP-225 Department of Food and Resource Economics, University of Florida, Gainesville, FL.

Castel, J.R., I. Bautista, C. Ramos, and G. Cruz. 1987. Evapotranspiration and irrigation efficiency of mature orange orchards in Valencia (Spain). Irrig. Drain. Syst. 3:205-217.

Chaudhury, T.N. 1985. Response of wheat to irrigation with small amount of water applied in various ways. Agr. Water Mgt. 10:357-364.

Chen, D., Y. Wang, S. Liu, X. Wei, and X. Wang. 2014. Response of relative sap flow to meteorological factors under different soil moisture conditions in rainfed jujube (Ziziphus jujuba Mill.) plantations in semiarid northwest China. Agr. Water Mgt. 136:23-33.

Chone, X., C. van Leeuwen, D. Dubourdieu, and J.P. Gaudillere. 2001. Stem water potential is a sensitive indicator of grapevine water status. Ann. Bot. 87:477-483.

Dynamax. 1990. Dynagage installation and operation manual. Dynamax, Houston, TX.

Fares, A. and A.K. Alva. 1999. Estimation of citrus evapotranspiration by soil water mass balance. Soil Sci. 164:302-310.
Gasque, M., P. Marti, B. Beatriz Granero, and P. González-Altozano. 2016. Effects of long-term summer deficit irrigation on 'Navelina' citrus trees. Agr. Water Mgt. 169:140-147.

Graham, J.H., E.G. Johnson, T.R. Gottwald, and M.S. Irey. 2013. Pre-symptomatic fibrous root decline in citrus trees caused by Huanglongbing and potential interaction with Phytophthora spp. Plant Dis. 97:1195-1199.

Handique, U., R.C. Ebel, and K.T. Morgan. 2012. Influence of soil-applied fertilizer on greening development in new growth flushes of sweet orange. Proc. Florida State Hort. Soc. 125:36-39.

Haijun, L., S. Cohen, J.H. Lemcoff, Y. Israeli, and J. Tanny. 2015. Sap flow, canopy conductance and microclimate in a banana screenhouse. Agr. For. Meteorol. 201:165-175.

Hamido, S.A., K.T. Morgan, R.C. Ebel, and D.M. Kadyampakeni. 2017. Improved irrigation management of sweet orange with Huanglongbing. HortScience 52:916-921

Hamido, S.A., K.T. Morgan, and K.A. Mahmoud. 2016. Citrus Huanglongbing impact on citrus trees biomass and nutrients uptake. 13 Mar. 2017. <https:// scisoc.confex.com/scisoc/2016am/ webprogram/Paper99487.html>.

Hla, A.K., E.C. Martin, P.M. Waller, and D.C. Slack. 1997. Heat unit based crop coefficient for grapefruit trees. J. Appl. Eng. Agr. 13:485-489.

Igarashi, Y., G.G. Katul, T. Kumagai, N. Yoshifuji, T. Sato, N. Tanaka, K. Tanaka, H. Fujinami, M. Suzuki, and C. Tantasirin. 2015. Separating physical and biological controls on long-term evapotranspiration fluctuations in a tropical deciduous forest subjected to monsoonal rainfall. J. Geophys. Res. Biogeosci. 120:1262-1278.

Jia, X., A. Swancar, J.M. Jacobs, M.D. Dukes, and K.T. Morgan. 2007. Comparison of evapotranspiration rates for flatwoods and ridge citrus. Trans. Amer. Soc. Agr. Biol. Eng. 50:83-94.

Jensen, M.E., R.D. Burman, and R.G. Allen. 1990. Evapotranspiration and irrigation water requirements. ASCE Manuals Rpts. Eng. Practice No. 70. Amer. Soc. Civil Engineers, New York, NY.

Kadyampakeni, D.M., K.T. Morgan, A.W. Schumann, and P. Nkedi-Kizza. 2014a. Effect of irrigation pattern and timing on root density of young citrus trees infected with Huanglongbing disease. HortTechnology 24:209-221.

Kadyampakeni, D.M., K.T. Morgan, A. W. Schumann, P. Nkedi-Kizza, and T.A. 
Obreza. 2014b. Water use in drip- and microsprinkler-irrigated citrus trees. Soil Sci. Soc. Amer. J. 78:1351-1361.

Ma, N., N. Wang, L. Zhao, Z. Zhang, C. Dong, and S. Shen. 2014. Observation of megadune evaporation after various rain events in the hinterland of Badain Jaran Desert, China. Chin. Sci. Bull. 59:162170.

McCutchan, H. and K.A. Shackel. 1992. Stem water potential as a sensitive indicator of water stress in prune trees. J. Amer. Soc. Hort. Sci. 117:607-611.

Moore, P.A., T.G. Pypker, and J.M. Waddington. 2013. Effect of long-term water table manipulation on peatland evapotranspiration. Agr. For. Meteorol. 178/179:106-119.

Morgan, K.T. 1992. Determination of evapotranspiration rates in citrus groves with electronic soil moisture probes. Proc. Florida State Hort. Soc. 105:63-66.

Morgan, K.T., T.A. Obreza, J.M.S Scholberg, L.R. Parsons, and T.A. Wheaton. 2006. Citrus water uptake dynamics on a sandy Florida Entisol. Soil Sci. Soc. Amer. J. 70:90-97.

Obreza, T.A., D.J. Pitts, L.R. Parsons, T.A. Wheaton, and K.T. Morgan. 1997. Soil water-holding characteristic affects citrus irrigation scheduling strategy. Proc. Florida State Hort. Soc. 110:36-39.

Rogers, J.S., L.H. Allen, and D.V. Calvert. 1983. Evapotranspiration from a developing citrus grove in a humid climate. Trans. Amer. Soc. Agr. Eng. 26:1778-1783.

Romero, C.C., M.D. Dukes, G.A. Baigorria, and R. Cohen. 2009. Comparing theoretical irrigation requirement and actual irrigation for citrus in Florida. Agr. Water Mgt. 96:473-483.
Salifu, A.W., K. Grogan, T. Spreen, and F. Roka. 2012. The economics of the control strategies of HLB in Florida citrus. Proc. Florida State Hort. Soc. 125:22-28.

Shackel, K.A., H. Ahmadi, and W. Biasi. 1997. Plant water status as an index of irrigation need in deciduous fruit trees. HortTechnology 7:23-29.

Yang, S.L., M. Aydin, T. Yano, and X. Li. 2003. Evapotranspiration of orange trees in greenhouse lysimeters. Irr. Sci. 21:145-149.

Zotarelli, L., M.D. Dukes, C.C. Romero, K.W. Migliaccio, and K.T. Morgan. 2010. Step by step calculation of the PenmanMonteith evapotranspiration (FAO-56 method), Univ. of Florida, Inst. Food Agr. Sci., Florida Coop. Ext. Serv., Agr. Biol. Eng. Dept., Gainesville. 